Coutespondente.

"Audi alteram partem."

\section{ORAL SEPSIS AND THE EXTRACTION OF TEETH.}

To the Editor of THE LANOET.

SIR,-May I put my finger at once. on the weak spot of Sir James Goodhart's protest in THE LANCET of July 25th against "wholesale" extraction of teeth? It lies in the sentence, "I examined his mouth very carefully, and his teeth were to my eye perfect." It is exactly the failure on the part both of doctor and dentist to realise on the one hand the amount of dental sepsis, and on the other the extent to which the tissues resent its presence-i.e., the local signs of inflammation and destruction or hypertrophy of tissue - that leads to the present conflict of opinion. Sir James Goodhart asserts that "pyorrhœa" is a painful malady; pain is an uncertain symptom, often absent through the whole course of the disease. His description of "pyorrhcea" as deep-seated, pent-up suppuration in the alveoli does not apply to the great majority of cases met with in dental practice. Pent-up pus means acute abscess and pain, but the usual case of "pyorrhcea" presents at the necks of the teeth freely discharging sinuses; if a sinus become blocked, then there is the acute state Sir James Goodhart refers to. He also speaks of "trivial ulceration of the edges of the gums." The ulceration of "pyorrhœa" is not found patent on the edges of the gums; it is hidden on the tooth-ward side of the gum-fiaps that help to form the pockets of "pyorrhœa." Perhaps I may be excused for suggesting that Sir James Goodhart's protest may not be so well founded as at first sight it seems.

Till lately teeth were preserved at all costs, and perhaps the swing of the pendulum has in some individual cases gone too far. I suspect we could all relate cases in which we have saved the patient's teeth after "wholesale" extraction has been advised, but my daily experience convinces me that in the gross more good is done by "wholesale" extraction of teeth that are suspect than by conservation. The more intimate knowledge that $\mathrm{X}$ rays give us, increasing clinical experience, and the study of large numbers of skulls stored in our museums so far from tending to contract my horizon of the evils and extent of dental sepsis tend continually to widen it. I may add that at the museum of the International Dental Congress now being held in London, August 3rd-8th, at the Imperial College of Scienceand Technology, South Kensington, I am exhibiting a large series of jaws showing the bone changes of "pyorrhcea."

I am, Sir, yours faithfully,

Wimpole-street, W., July 31st, 1914. J. G. TURNER.

To the Editor of THE LANCET.

SIR,-It is very clear from Sir James Goodhart's letter that he has not devoted the special attention necessary to make himself acquainted with the methods of diagnosing periodontal disease. Had he taken the trouble to wrap a wisp of cotton-wool round a very thin bristle and gently passed this round each tooth in the case he mentions he would probably have found "pockets" round the condemned teeth. Then had he warmed the bristle after withdrawing it from these pockets and held it under his nose he might possibly have had some glimmering as to the justice of the condemnation. Further, had he had a skiagraph taken to show the condition of the alveolar processes he would probably have seen areas of rarefying osteitis and possibly even abscess cavities round some of the roots. There are many such cases where there is no pus at the gum margin and very little gingivitis presentcases where unless a proper, careful, and scientific examination is made the mouths may easily be passed as being healthy, and they are passed daily by great numbers of practitioners who have not devoted enough attention to this subject. Yet it is these same cases which so frequently give rise to grave joint lesions and many other maladies too numerous to mention here. This type of pyor. rhoea, by the way, never gives rise to pain.

Further, if Sir James Goodhart would attend the out-patient department of one of the numerous hospitals in London where these cases are diagnosed and thoroughly treated, he would be astonished at the innumerable instances of very marked improvement in the general health of the patients who have had "perfectly sound teeth" (according to the general public) removed.

I am, Sir, yours faithfully,

Frank St. J. Steadman,

Assistant Dental Surgeon to the Royal Dental Hospital. Queen Anne-street, W., July 27th, 1914.

\section{To the Editor of THE LANCET.}

SIR,-I desire as a dental surgeon to a London hospital to support Sir James F. Goodhart's contention in THE LANCET of July 25th, that "a harmful practice has come into vogue that needs to be held up." Extreme methods are usually wrong. I have to see a great many dirty mouths in which there is no deep-seated suppuration, and my experience confirms the view that scaling of the teeth and the use of the toothbrush twice daily with a corrected dietary yield quite marvellous results. The term pyorrhœea has been used too often loosely to cover all conditions of oral sepsis.

A condition of asepsis is impossible in any mouth, therefore the term is relative. Teeth that are firm enough to be used in mastication should be saved. It is quite easy to remore all the teeth, but not so easy to restore the function of mastication, with an abundant flow of saliva and all the values of trituration of foods in the mouth.

I shall not trespass on your space fully to argue the matter out; I quote my thirty years' experience only in support of my opinion.

I am, Sir, yours faithfully, GEORGE THOMSON,

Honorary Dental Surgeon to the Royal Hospital for Diseases of the Chest, \&c.

Harley-street, W., July 28th, 1914.

\section{THE WORKING OF THE NATIONAL INSURANCE ACT IN GREAT YARMOUTH. To the Editor of THe LanceT.}

SIR,-Dr.R.H. Shaw, who I understand was one of your Special Correspondent's informants, has come forward to carroborate presumably his own statements. They do not agree with what other informants who are on the panel said, and as there is no hope for peace in Yarmouth medical circles until a clear understanding is arrived at $I$ beg you to insert a full statement from me.

With regard to allocation, Dr. Shaw was present at one, and only one, meeting of the panel doctors 